Available online at GSC Online Press Directory

GSC Biological and Pharmaceutical Sciences

e-ISSN: 2581-3250, CODEN (USA): GBPSC2

Journal homepage: https://www.gsconlinepress.com/journals/gscbps

(RESEARCH ARTICLE)

\title{
Evaluation of thyroid disorders in cotton growers exposed to pesticides in Satiri department
}

Bazoma Bayili 1, 2, , Ollo Da 2, 3, Jean Fidèle Bationo ${ }^{4}$, Véronique Panne Coulibaly 2, Sylvain Ilboudo 5, 6 , Richard Ouedraogo 6,7, Jean Bosco Ouedraogo ${ }^{1}$ and Georges Anicet Ouedraogo ${ }^{2}$

${ }^{1}$ Institut de Recherche en Sciences de la Santé (IRSS), Direction Régional de l'Ouest (DRO), Bobo-Dioulasso, Burkina Faso. 399, Avenue de la Liberté. 01 BP: 545, Tel :(+226) 704481 65, Fax: (+226) 20974868.

2 Université Nazi Boni (UNB), Bobo Dioulasso, Burkina Faso. 01 BP 1091 Tél : (+226) 20980635, Fax (+ 226$) 20982577$.

${ }^{3}$ Département de Laboratoire, service de biochimie, Centre Hospitalier Universitaire Souro SANOU, Bobo-Dioulasso, Burkina Faso. 01 BP. 676. Tel. $+22620970044 /+22620970045$

${ }^{4}$ Centre Muraz, Bobo Dioulasso, Burkina Faso. 01 BP 390. Tél: (+ 226) 20970102.

5 Institut de Recherche en Sciences de la Santé (IRSS), Ouagadougou, Burkina Faso. 03 B.P. 7192. Tél: (+226) 253632 15, Fax (+226) 25360394 .

6 Unité mixte de Recherche Internationale - Environnement, santé et société (UMI 3189, ESS) CNRS/UCAD/UGB/USTTB/CNRST.

${ }^{7}$ Institut de l'Environnement et de Recherches Agricoles, Direction Régionale de Recherche Environnementale et Agricole de l'Ouest (INERA/DRREA-O), Farako-Ba, Bobo Dioulasso, Burkina Faso.

Publication history: Received on 02 September 2020; revised on 16 October 2020; accepted on 22 October 2020

Article DOI: https://doi.org/10.30574/gscbps.2020.13.1.0325

\begin{abstract}
Cotton farmers are exposed to a variety of pesticide formulations, some of which contain active endocrine disrupting substances. The objective of this study was to investigate the link between pesticide exposure and thyroid disorders in cotton growers.

This was a longitudinal prospective study among cotton producers during and after the 2018/2019 cotton season in the Satiri department. Surveys have been conducted on a cohort of 50 producers to collect socio-demographic and professional information on the producers and the pesticides used. A medical examination of the producers followed by blood samples were carried out during and after the cotton season. The thyroid stimulating hormone (TSH), Free tetraiodo-thyronine (FT4) and Free tri-iodo-thyronine (FT3) biomarkers were measured on the Cobas $₫ 6000$ automaton. During the cotton campaign, an overall frequency of $12.00 \%$ of dysthyroidism, of which $8.00 \%$ of hypothyroidism and $4.00 \%$ of hyperthyroidism were recorded. After the campaign, $14.00 \%$ dysthyroidism was observed, including $8.00 \%$ of hypothyroidism and $6.00 \%$ of hyperthyroidism. Also, a significant decrease in TSH concentrations; a significant increase in FT4 and a non-significant decrease in FT3 were observed.
\end{abstract}

This study does not establish a specific link between exposure to pesticides and thyroid disorders due to the complexity and cocktail effect of pesticides. Rational use of these products is essential to avoid health effects linked to endocrine disruption.

Keywords: Pesticides; Producers; Cotton; Thyroid; Dysthyroidism

\footnotetext{
${ }^{*}$ Corresponding author: Bazoma BAYILI

Institut de Recherche en Sciences de la Santé (IRSS), Direction Régional de l'Ouest (DRO), Bobo-Dioulasso, Burkina Faso. 399, Avenue de la Liberté. 01 BP : 545, Tel :( +226) 7044 81 65, Fax : (+ 226) 20974868. 


\section{Introduction}

While accounting for only a modest portion of GDP (an average of 2.5 percent over the past decade), cotton export revenues have provided Burkina Faso with a stable source of foreign currency that has catalyzed economic development in other sectors [1]. Globally, Burkina Faso is a top-10 exporter of cotton, accounting for an average share of 3 percent of global exports since 2000. At the national level, the production and ginning of cotton is of prime importance to the Burkinabe economy [1]. Cotton is a major source of employment, and has created substantial economic multipliers through the development of the sector's value chain and the physical infrastructure it requires [1]. However, cotton production is heavily dependent on pesticides treatment as it faces various attacks from pests. Indeed, yield losses in seed cotton due to weed competition are of the order of $20 \mathrm{~kg} /$ ha per day of weeding delay, compared to the optimal weeding date [2]. Also, in the absence of insecticide treatments in cotton cultivation, the pressure of harmful insects leads to yield losses of up to $70 \%[3]$.

However, the use of pesticides can cause toxicity for users in the agricultural environments, particularly applicators [4]. A survey carried out in three regions in western Burkina Faso in 2016 revealed 107 cases of poisoning out of 509 producers [5]. Many pesticides are associated with the development of breast cancer, reduced male fertility, reduced immune system, obesity, bones decalcification and damage to the thyroid gland [6].

The previous decade has seen the publication of a substantial number of studies whose overall conclusion is that there is a risk of altering the serum thyroid hormones concentrations through exposure to certain chemical [7, 8]. In addition, lambda-cyhalothrin, flubendiamide, chlorpyriphos-ethyl, spirotetramate induce a decrease in the thyroid hormones T3 and T4 and deltametrin leads to an alteration of the thyroid hormones [9]. The chemical families of pesticides found in the cotton zone include less persistent pesticides such as organophosphates, carbamates and pyrethroids [10]. These chemical families of pesticides have been associated with changes in the levels of tri-iodo-thyronine (T3), tetra-iodothyronine (T4) and thyroid stimulating hormone (TSH) [11]. A disturbance in thyroid activity could lead to muscle weakness and cramps, an acceleration or slowing of the heart rate, weight loss or gain, trembling of the extremities, general fatigue (physical and mental) [12].

In Burkina Faso in general and in the western cotton zone in particular, the use of pesticides dates back several years. The toxicological profile linked to chronic exposure is less documented or is given in hypothetical form or by transposition with effects linked to similar situations coming from other countries. Most of the producers in the Satiri cotton zone have very long experience in the use of pesticides. Anything that could generate health risks related to the disruption of the thyroid gland. The general objective of this study is to assess thyroid disorders in cotton farmers during and after the 2018/2019 cotton season in the Satiri department.

\section{Methodology}

\subsection{Study type and period}

This study is of a longitudinal prospective type. It was carried out during and after the 2018/2019 cotton campaign with a first stage in September 2018 in the middle of a pesticide application and a second stage in April 2019, approximately 06 months after the applications.

\subsection{Study setting}

The study took place in the SATIRI department located in the Bobo Dioulasso cotton growing region. This department is an important cotton region of the Burkinabè Textile Fibers Company (SOFITEX). This locality is located about fifty north-east of the town of Bobo Dioulasso in the province of Houet in the west of Burkina Faso (figure 1). Three villages bordering the Biosphere reserve of the Bala hippopotamus pond were involved in the study. These were Balla, Sokourani and Tiarako. The administration of the questionnaire and the medical visits took place simultaneously in the health and social promotion centers (CSPS) of Bala and Tiarako. The analysis of blood samples for the determination of thyroid hormones was carried out in the laboratory department of CHUSS. 


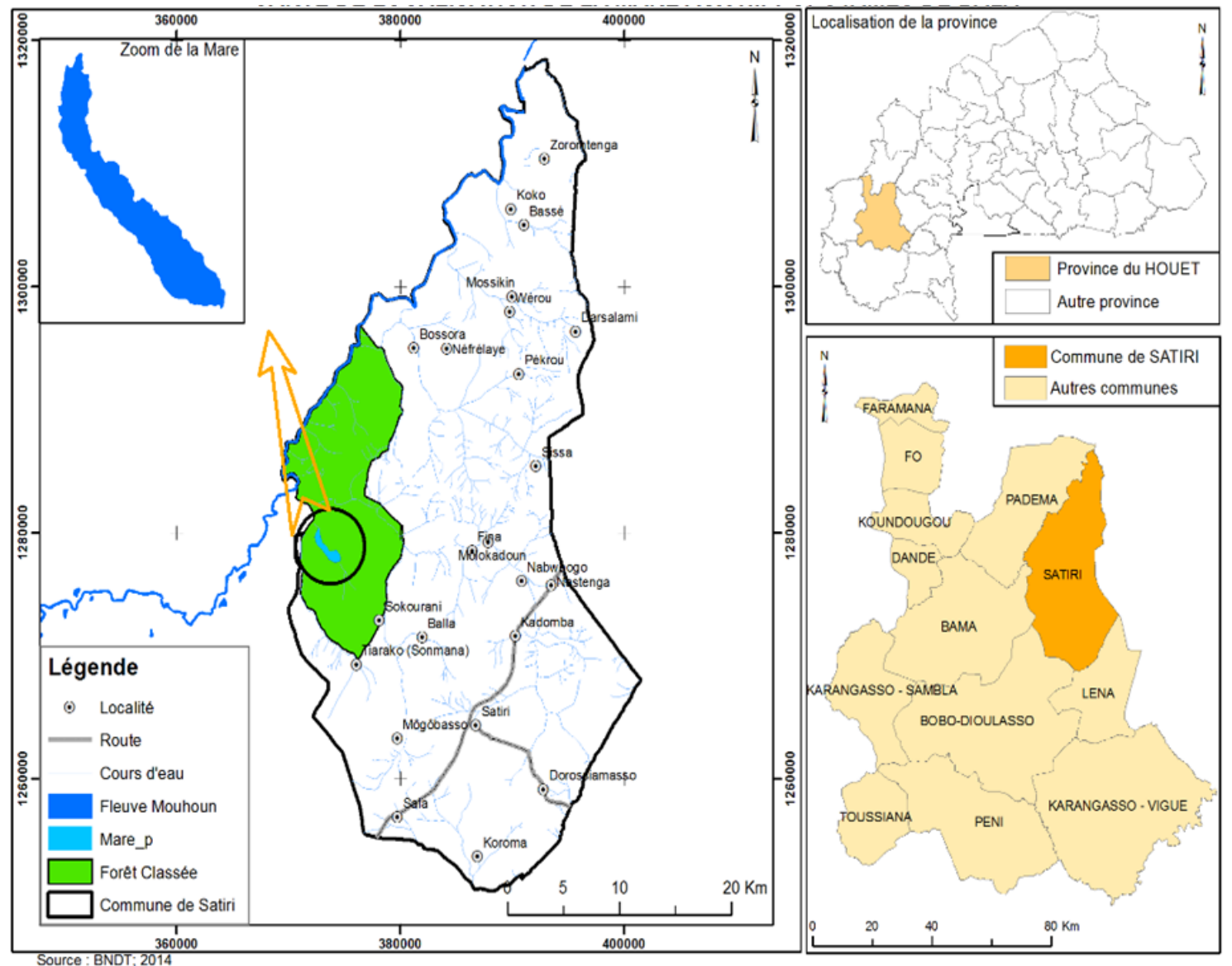

Figure 1 Location of the study site

\subsection{Conduct of the investigation}

Producers levied received a medical examination in addition to an individual questionnaire administered to each producer in the CSPS. This survey collected information on their medical history (chronic diseases such as diabetes, high blood pressure (hypertension), neurological and liver disorders, and the use of anti-inflammatory drugs such as non-steroidal anti-inflammatory drugs or corticosteroids). Socio-professional information and phytosanitary practices were also collected. During the medical visits, measurements of physiological constants (temperature, blood pressure, pulse, and respiratory rate), physical, anthropometric measurements (weight, height) were collected before each sampling phase. Following the collection of this information, blood samples were taken for the assay of biochemical parameters.

In a study on the same site, producers were surveyed to determine agricultural practices (pesticides used, methods of using pesticides, etc.). The pesticides identified have been characterized (registration status, active ingredients used, toxicological class according to the WHO, endocrine disruption status). Pesticide properties databases (PPDB) were used.

\subsection{Study population}

The study involved all cotton producers in the villages of Bala, Tiarako and Sokourani. These producers are organized into a cotton producer group (GPC). The study sample was therefore drawn up on the basis of 20 GPCs from 513 producers in the Satiri department.

In addition, individuals had to meet inclusion criteria and sign a duly explained consent form.

\subsection{Inclusion and non-inclusion criteria}

The sampling frame should include people from these three localities with the following characteristics: 
- Owning a cotton farm in the study area ;

- Apply pesticides on the farm during the $2018 / 2019$ cotton campaign ;

- Take part in blood samples during and after the 2018/2019 cotton campaign.

In addition to its inclusion criteria, this study excluded:

- Producers who do not use pesticides;

- Producers who took part in a single sampling stage.

\subsection{Sampling and study variables}

This was an exhaustive sampling which involved all volunteer cotton producers meeting the inclusion criteria. The variables considered were: socio-demographic variables: age, sex, height, weight; the pesticide used, the level of education, signs of poisoning, medical history, functional disorders and biological examinations: FT4 (T4 free), FT3 (T3 free) and TSH. Finally, a cohort of 50 farmers was selected for follow-up.

\subsection{Assay of thyroid hormones}

The blood samples were taken by venipuncture with strict asepsis. Thus, $3 \mathrm{ml}$ of whole blood were collected in dry tubes, stored in coolers and transported to the CHUSS laboratory of Bobo-Dioulasso where the specimens were centrifuged, aliquoted and stored at $-20^{\circ} \mathrm{C}$.

The serum samples were assayed with the Cobas ${ }^{\circledR} 6000$ biochemistry analyzer according to the principle of immunoassay coupled with an electro-chemiluminescent reading. The reagents used were elecsys TSH, elecsys FT4 and elecsys FT3. The table 1 shows thyroid hormones and their reference Intervals with the Cobas 8000.

Table 1 Thyroid hormones and their reference Intervals with the Cobas® 6000.

\begin{tabular}{|l|l|}
\hline Thyroid hormones & Reference Intervals \\
\hline Thyroid Stimulating Hormone (TSH) & $0.27-4.20(\mu \mathrm{lU} / \mathrm{mL})$ \\
\hline Free tetra iodo-thyronine (FT4) & $12.00-22.00(\mathrm{pmol} / \mathrm{L})$ \\
\hline Free tri iodo-thyronine (FT3) & $3.90-6.60(\mathrm{pmol} / \mathrm{L})$ \\
\hline
\end{tabular}

\subsection{Data analysis methods}

The determination of pesticides, their active ingredients, chemical families and their toxicity classes according to the WHO has been established in relation to the names of the specialties identified using the global list of authorised pesticides by the Sahelian Pesticides Committee (CSP) version of May 2018 as well as international databases on the properties of pesticides (PPDB). Word 2016, XLSAT 2014 and EXCEL 2016 spreadsheets were used for the various analyzes. The Pearson correlation test was used with a significance level of 5\%.

\subsection{Ethical considerations}

The study protocol was submitted and obtained the favorable opinion of the Ethics Committee for Health Research (CERS) of Burkina Faso, deliberation $\mathrm{n}^{\circ}$ 2018-7-083.

\section{Results and discussion}

\subsection{Sociodemographic and anthropological data on producers}

Sociodemographic data of the growers are shown in table 2. All 50 farmers were male. The age median of producers was 40.5 with extremes ranging from 18 to 57 years. The median BMI of producer was 21.12 with extremes ranging from 17.40 to 28 . 08. Furthermore, the majority of producers were illiterate, $52.00 \%(26 / 50)$. 
Table 2 Sociodemographic characteristics of growers

\begin{tabular}{|c|c|}
\hline \multicolumn{2}{|l|}{ Sexe } \\
\hline Male & $100 \%$ \\
\hline Woman & $0.00 \%$ \\
\hline \multicolumn{2}{|l|}{ Age group } \\
\hline$[15-30[$ & $24.00 \%$ \\
\hline$[30-45[$ & $34.00 \%$ \\
\hline$[45-60[$ & $42.00 \%$ \\
\hline Median & 40.50 years \\
\hline Mean \pm standard deviation & $39,52 \pm 10,77$ years \\
\hline \multicolumn{2}{|l|}{ Body Mass Index (BMI) } \\
\hline $\mathrm{BMI} \leq 19 \mathrm{~kg} / \mathrm{m}^{2}$ & $10.00 \%$ \\
\hline $19<\mathrm{BMI} \leq 25 \mathrm{~kg} / \mathrm{m}^{2}$ & $82.00 \%$ \\
\hline $25<\mathrm{BMI} \leq 30 \mathrm{~kg} / \mathrm{m}^{2}$ & $8.00 \%$ \\
\hline Extreme values & $17.40-28.08 \mathrm{~kg} / \mathrm{m}^{2}$ \\
\hline Median & $21.12 \mathrm{~kg} / \mathrm{m}^{2}$ \\
\hline \multicolumn{2}{|l|}{ Education } \\
\hline Illiterate & $52.00 \%$ \\
\hline Primary level & $26.00 \%$ \\
\hline Secondary level & $22.00 \%$ \\
\hline Higher level (Bac +) & $0.00 \%$ \\
\hline
\end{tabular}

\subsection{Characterization of the pesticides used}

Table 3 Describes the pesticides identified by producers during the 2018-2019 campaign. Pesticides were dominated by herbicides (77.78\%), followed by insecticides (18.52\%) and fungicides (3.70\%). Among these pesticides $88.88 \%$ were registered by the CSP. The active substances that are proven and possible thyroid disrupting agents are also given.

Table 3 Pesticides encountered from producers list.

\begin{tabular}{|c|c|c|c|c|c|c|c|}
\hline $\begin{array}{l}\text { Commercial } \\
\text { formulation }\end{array}$ & $\begin{array}{l}\text { Type of } \\
\text { pesticid } \\
\text { e }\end{array}$ & $\begin{array}{l}\text { WH } \\
0 \\
\text { class }\end{array}$ & $\begin{array}{l}\text { Registratio } \\
\text { n status }\end{array}$ & $\begin{array}{l}\text { Active substances } \\
\text { (a.s.) }\end{array}$ & Group of substances & $\begin{array}{l}\text { WH } \\
\text { O } \\
\text { class } \\
\text { of } \\
\text { a.s. }\end{array}$ & $\begin{array}{l}\text { Endocrin } \\
\mathrm{e} \\
\text { disruptio } \\
\mathrm{n}\end{array}$ \\
\hline \multirow{2}{*}{ ACERO 84 EC } & \multirow{2}{*}{ I } & \multirow{2}{*}{ II } & \multirow{2}{*}{ Yes } & $\begin{array}{l}\text { Isoclast } \\
\text { (sulfoxaflor) }\end{array}$ & Sulfoximine & III & No data \\
\hline & & & & $\begin{array}{l}\text { Lambda- } \\
\text { cyhalothrin }\end{array}$ & Pyrethroid & II & No \\
\hline ACTION 80 DF & $\mathrm{H}$ & III & Yes & Diuron & Phenylamide & III & Possible \\
\hline $\begin{array}{l}\text { ADWUMA } \\
\text { WURA }\end{array}$ & $\mathrm{H}$ & $\mathrm{U}$ & No & Glyphosate & Phosphonoglycine & III & Possible \\
\hline $\begin{array}{l}\text { AVAUNT } 150 \\
\text { EC }\end{array}$ & I & III & Yes & Indoxacarb & Oxadiazine & II & Possible \\
\hline
\end{tabular}




\begin{tabular}{|c|c|c|c|c|c|c|c|}
\hline $\begin{array}{l}\text { DIGA- } \\
\text { FAGALAN } 360 \\
\text { SL }\end{array}$ & $\mathrm{H}$ & III & Yes & Glyphosate & Phosphonoglycin & III & Possible \\
\hline $\begin{array}{l}\text { DIURALM } 80 \\
\text { WG }\end{array}$ & $\mathrm{H}$ & III & Yes & Diuron & Phenylamide & III & Possible \\
\hline \multirow{2}{*}{ EMAPYR } & \multirow[t]{2}{*}{ I } & \multirow[t]{2}{*}{ III } & \multirow[t]{2}{*}{ Yes } & $\begin{array}{l}\text { Emamectin } \\
\text { benzoate }\end{array}$ & $\begin{array}{ll}\text { Derived } & \text { from } \\
\text { microorganisms } & \\
\end{array}$ & II & No data \\
\hline & & & & Pyriproxyfen & Pyridine derived & $\mathrm{U}$ & Possible \\
\hline $\begin{array}{l}\text { GALLANT } \\
\text { SUPER }\end{array}$ & $\mathrm{H}$ & III & Yes & $\begin{array}{l}\text { Haloxyfop-p- } \\
\text { methyl }\end{array}$ & $\begin{array}{l}\text { Aryloxyphenoxypropiona } \\
\text { te }\end{array}$ & II & No data \\
\hline $\begin{array}{l}\text { GLYCEL } 410 \\
\text { SL }\end{array}$ & $\mathrm{H}$ & II & Yes & Glyphosate & Phosphonoglycin & III & Possible \\
\hline $\begin{array}{l}\text { GLYPHADER } \\
75 \mathrm{SG}\end{array}$ & $\mathrm{H}$ & III & Yes & Glyphosate & Phosphonoglycin & III & Possible \\
\hline $\begin{array}{l}\text { GLYPHADER } \\
360 \mathrm{SL}\end{array}$ & $\mathrm{H}$ & $\mathrm{U}$ & Yes & Glyphosate & Phosphonoglycin & III & Possible \\
\hline GLYPHE & $\mathrm{H}$ & $\mathrm{U}$ & Yes & Glyphosate & Phosphonoglycin & III & Possible \\
\hline $\begin{array}{l}\text { GLYPHOBAR } \\
480 \mathrm{SL}\end{array}$ & $\mathrm{H}$ & III & Yes & $\begin{array}{l}\text { Glyphosate, } \\
\text { isopropylaminesa } \\
\text { lt }\end{array}$ & Phosphonoglycin & III & No \\
\hline $\begin{array}{l}\text { GRAMOSHAP } \\
\text { SUPER }\end{array}$ & $\mathrm{H}$ & II & No & $\begin{array}{l}\text { Paraquat } \\
\text { dichloride }\end{array}$ & $\begin{array}{l}\text { Quaternary ammonium } \\
\text { compound }\end{array}$ & II & No \\
\hline $\begin{array}{l}\text { HALONET } 104 \\
\text { EC }\end{array}$ & $\mathrm{H}$ & III & Yes & $\begin{array}{l}\text { Haloxyfop-p- } \\
\text { methyl }\end{array}$ & $\begin{array}{l}\text { Aryloxyphenoxypropiona } \\
\text { te }\end{array}$ & II & No data \\
\hline \multirow{2}{*}{$\begin{array}{l}\text { IMIDALM-T } \\
450 \mathrm{WS}\end{array}$} & \multirow{2}{*}{$\mathrm{F}$} & \multirow{2}{*}{ II } & \multirow[t]{2}{*}{ Yes } & Imidacloprid & Neonicotinoid & II & No data \\
\hline & & & & Thiram & Carbamate & II & Possible \\
\hline $\begin{array}{l}\text { KALACH } 360 \\
\text { SL }\end{array}$ & $\mathrm{H}$ & III & Yes & Glyphosate & Phosphonoglycin & III & Possible \\
\hline KILLER 450 SL & $\mathrm{H}$ & $\mathrm{U}$ & Yes & Glyphosate & Phosphonoglycin & III & Possible \\
\hline LADABA & $\mathrm{H}$ & $\mathrm{U}$ & No & Glyphosate & Phosphonoglycin & III & Possible \\
\hline $\begin{array}{l}\text { LAMACHETTE } \\
360 \mathrm{SL}\end{array}$ & $\mathrm{H}$ & III & Yes & Glyphosate & Phosphonoglycin & III & Possible \\
\hline \multirow{2}{*}{$\begin{array}{l}\text { LIBERATOR } \\
500 \mathrm{SC}\end{array}$} & \multirow{2}{*}{$\mathrm{H}$} & \multirow{2}{*}{ III } & \multirow[t]{2}{*}{ Yes } & Diflufenican & Carboxamide & III & No data \\
\hline & & & & Flufenacet & Oxyacetamide & II & No data \\
\hline $\begin{array}{l}\text { NICOMAIS } 40 \\
\text { SC }\end{array}$ & $\mathrm{H}$ & III & Yes & Nicosulfuron & Sulfonylurea & $\mathrm{U}$ & No data \\
\hline POWER & $\mathrm{H}$ & III & Yes & Diuron & Phenylamide & III & Possible \\
\hline \multirow{2}{*}{$\begin{array}{l}\text { PYRINEXQUIC } \\
\text { K } 424 \mathrm{EC}^{2}\end{array}$} & \multirow[b]{2}{*}{ I } & \multirow[b]{2}{*}{ II } & \multirow[t]{2}{*}{ Yes } & Deltamethrin & Pyrethroid & II & Yes \\
\hline & & & & $\begin{array}{l}\text { Chlorpyrifos- } \\
\text { ethyl }\end{array}$ & Organophosphate & III & Possible \\
\hline $\begin{array}{l}\text { ROUNDUP } 360 \\
\text { XL }\end{array}$ & $\mathrm{H}$ & III & Yes & Glyphosate & Phosphonoglycin & III & Possible \\
\hline $\begin{array}{l}\text { SEGAIBANA } \\
40 \mathrm{SC}\end{array}$ & $\mathrm{H}$ & $\mathrm{U}$ & Yes & Nicosulfuron & Sulfonylurea & $\mathrm{U}$ & No data \\
\hline \multirow{2}{*}{$\begin{array}{l}\text { TIHAN175 0- } \\
\text { TEQ }\end{array}$} & \multirow{2}{*}{ I } & \multirow{2}{*}{ III } & \multirow[t]{2}{*}{ Yes } & Spirotetremate & Tetramicacid & III & No \\
\hline & & & & Flubendiamide & Benzene-dicarboxamide & III & yes \\
\hline
\end{tabular}




\subsection{Thyroid hormone analysis}

Table 4 and figure 2 presents the distribution of producers according to dysthyroidisms (hypothyroidism and hyperthyroidism). Producers with an organic euthyroidism were distributed as follows: $88.00 \%$ during the campaign and $86.00 \%$ after the cotton campaign. An evolution of $2.00 \%$ was observed following a comparison between the dysthyroidisms observed during and after the 2018/2019 cotton campaign. A significant decrease in TSH concentrations; a significant increase in FT4 concentrations and a non-significant decrease in FT3 concentrations (table 5 and figure 3 ).

Table 4 Dysthyroïdism during and after the campaign.

\begin{tabular}{|l|l|l|l|}
\hline Period & Dysthyroïdism & Effective & Frequency (\%) \\
\hline \multirow{3}{*}{ During } & Hypothyroïdism & 4 & 8.00 \\
\cline { 2 - 4 } & Hyperthyroïdism & 2 & 4.00 \\
\hline \multirow{2}{*}{ Total } & Hypothyroïdism & 6 & 12.00 \\
\hline \multirow{2}{*}{ After } & Hyperthyrö̈dism & 4 & 8.00 \\
\hline Total & 3 & 6.00 \\
\hline
\end{tabular}

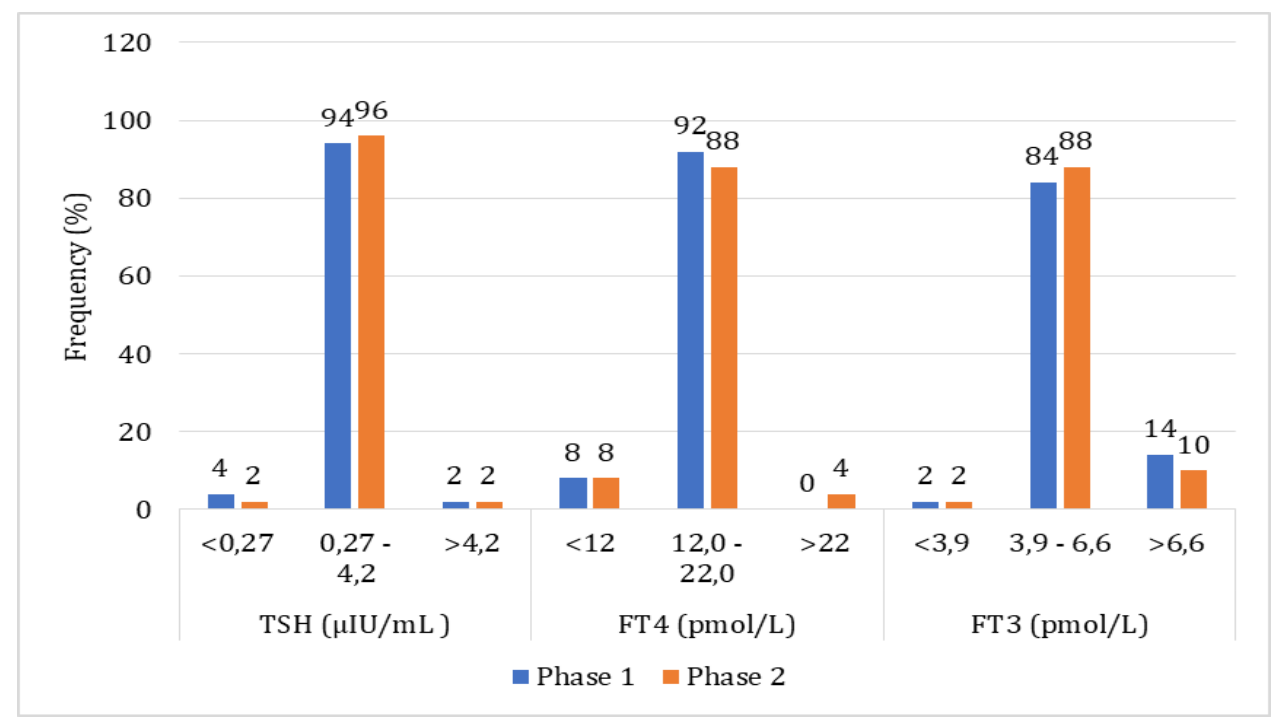

Figure 2 Producers repartition according to the reference values of thyroid hormones

Table 5 Evolution of producers thyroid hormones concentration.

\begin{tabular}{|l|l|l|l|}
\hline Parameters & 1st phase $(\mathrm{n}=50)$ & 2nd phase $(\mathrm{n}=50)$ & pvalue \\
\hline TSH $(\mu \mathrm{IU} / \mathrm{mL})$ & $1.4971 \pm 1.0770$ & $1.3804 \pm 0.8860$ & $<0.0001$ \\
\hline FT3 $(\mathrm{pmol} / \mathrm{L})$ & $5.6678 \pm 0.8758$ & $5.6024 \pm 0.7218$ & 0.1309 \\
\hline FT4 $(\mathrm{pmol} / \mathrm{L})$ & $15.5442 \pm 2.4739$ & $16.1368 \pm 2.7552$ & $<0.0001$ \\
\hline
\end{tabular}




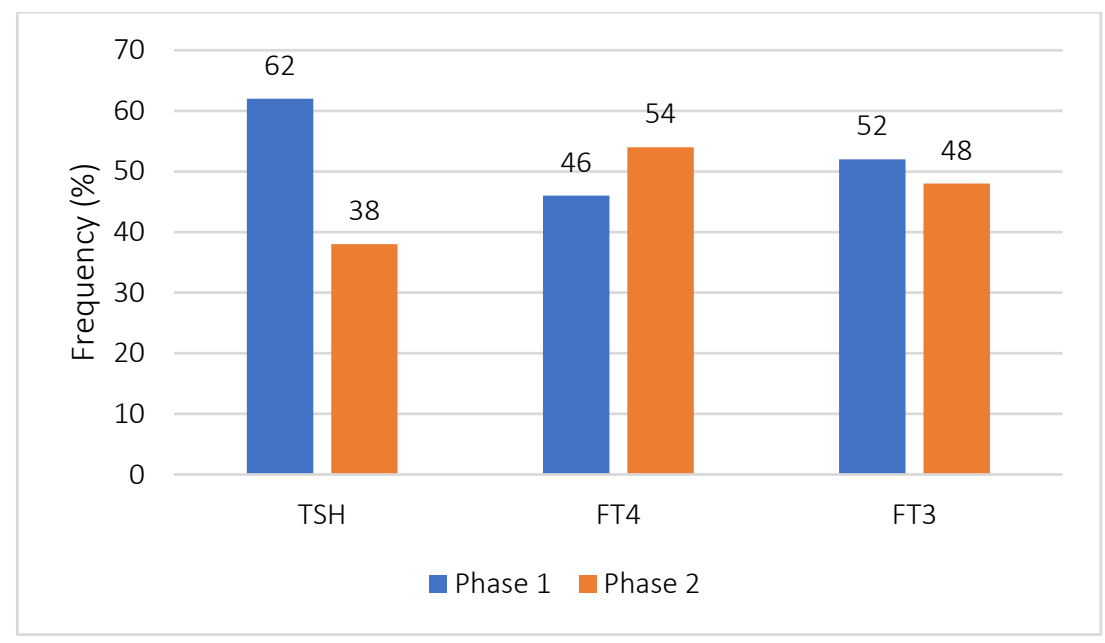

Figure 3 Producer repartition according to TSH, FT4 and FT3 concentration variation

\section{Discussion}

The total population studied was male. This masculinity already observed in the use of pesticides in agricultural areas $[5,13,14]$ could be explained by the fact that the application of pesticides is an activity attributed to men taking into account the arduousness and risks linked to the use of pesticides. Also, in cotton production, conventional cotton cultivation is mainly men activity, whereas in organic cotton production both sexes are involved.

The youngest producer was 18 years old and the oldest was 57 years old. This trend has been observed in agricultural areas in the west of Burkina Faso where several age categories have been noted, ranging from young people to the elderly involved in the use of pesticides [5]. The 45-60 age group, representing older adults, was predominant. The latter could be a risk factor for worsening the effects of exposure to pesticides. To show the influence of age in sensitivity to the effects of pesticides, Pope [15] has shown through several authors that immature people (young) and older adults are more sensitive to most classes of pesticides. Most producers have a normal BMI. However, almost $18 \%$ combine underweight and overweight. Researchers have shown a link between exposure to insecticides in particular and an increased risk of obesity and diabetes $[16,17]$. Knowing that weight loss or obesity is also thought to be partly linked to thyroid function disruption [18]. Exposure to pesticides affecting this function could cause weight problems.

Growers used three types of pesticides, namely insecticides, herbicides and fungicides. Several active substances such as deltametrin and flubendiamide are endocrine disruptors and chlorpyrifos-ethyl, diuron, glyphosate, indoxacarb, pyriproxyfen and thiram are probable endocrine disruptors [19]. In addition, the use of endocrine disrupting pesticides could lead to increases in the rate of cancers, neurodegenerative disorders, reproductive dysfunction, birth defects, respiratory disease, cardiovascular disease and aging. most of these diseases are related to exposure to insecticides [16]. Indeed, most biological functions are under the control of the endocrine system.

In this study, $88.00 \%$ and $86.00 \%$ of the growers during and after the cotton season had organic euthyroidism. Mean concentrations of TSH, FT4 and FT3 parameters respect the thyroid reference values. Hypothyroidism was observed at a frequency of $8.00 \%$ and hyperthyroidism was $4.00 \%$ and $6.00 \%$ respectively during and after the cotton campaign. This suggests that farmers may have been exposed to pesticides that affect thyroid function. Kongtip and al. [20] have shown that several specific herbicides have a significant relationship between the amount applied and an increase in thyroid hormones levels. These herbicides included paraquat (TSH, FT3 and T3); glyphosate (T4) and diuron (TSH) used by farmers and may have contributed to the observed cases of dysthyroidism. [21] showed that both cumulative and recent occupational exposure to agricultural pesticides could affect thyroid function, leading to hypothyroid-like effects, especially in men. Also, Campos and Freire [11] established through a cross-sectional study offering a comparison of the levels of thyroid hormones measured during the peak season of pesticide use and off-season hypothyroidism and hyperthyroidism.

This study showed a significant decrease in TSH concentrations, a significant increase in FT4 and a non-significant decrease in FT3 after the cotton campaign compared the results obtained during the cotton campaign. These results are comparable to those of Bernieri and al. [22], Who found in 2019 only a significant decrease in TSH and a significant increase in FT4 in rural workers compared to a control group. 


\section{Conclusion}

The present study aimed to assess thyroid disorders in cotton producers exposed to pesticides in the department of Satiri. This longitudinal prospective study took place during and after the 2018/2019 cotton campaign.

At the end of this study, dysthyroidisms of $12.00 \%$ and $14.00 \%$ were observed respectively during and after the cotton campaign. In addition to these dysthyroidism, a significant decrease in TSH concentrations, a significant increase in FT4 and a non-significant decrease in FT3 were observed. Several active substances making up the products used are endocrine disruptors (deltametrin and flubendiamide) or possible endocrine disruptors (chlorpyrifos-ethyl, diuron glyphosate, indoxacarb, pyriproxyfen and thiram).

The discussion showed that a level of variation in thyroid hormones seems nevertheless specific to each pesticide. The cocktail effect thus assessed may reveal trends that can go in several directions. More varied studies on different cotton facies involving larger groups could specify a more precise profile of the evolution of the concentrations of thyroid parameters.

\section{Compliance with ethical standards}

\section{Acknowledgments}

The author thanks the administrative, customary and cotton farmers organizations in the SATIRI department for organizational assistance. The sampling and analyzes were carried out thanks to the support of the biochemistry laboratory of the University Hospital Center Souro Sanou of Bobo-Dioulasso and technicians of the Research Institute in Health Sciences at the Regional Direction of the West. Bayili B., Da O., Bationo J.F., OUEDRAOGO J.B., wrote the protocol and the manuscript of the article. Bayili B., Da O., Coulibaly V. performed the assay of thyroid hormones in the laboratory as well as data analysis. All co-authors reviewed, edited and approved the manuscript.

\section{Disclosure of conflict of interest}

No conflict of interest was declared by any of the authors associated with this work.

\section{Statement of informed consent}

Informed consent was obtained from all individual participants included in the study.

\section{References}

[1] Jeffrey Vitale. Economic importance of cotton in Burkina Faso [internet]. Food and Agriculture Organization of the United Nations, Rome. 2018; [cited, 2020 Sep 25].

[2] Martin J, Gaudard L. Paraquat, diuron and atrazine to renew chemical weed control in North Cameroon. Agriculture and development, CIRAD-CA Montpellier, France. 1996; 11: 53-67.

[3] Traoré O. Positive development in integrated pest control for cotton in West Africa. 67th plenary meeting of the International Cotton Advisory Committee. Ouagadougou, Burkina Faso. 2008; [cited, 2020 Sep 25].

[4] Toé AM, Ouédraogo V, Guissou IP, Hema OSA. Contribution to agroindustrial toxicology in Burkina Faso. Study of poisonings of farmers by pesticides in the cotton area of Mouhoun. Results, analysis and proposals for taking charge of the problem. Journal of occupational medicine. 2002; 29: 59 - 64.

[5] Rotterdam Convention. Use of agricultural pesticides in three regions of Burkina Faso and evaluation of their impact on health and the environment: the case of the Boucle du Mouhoun, Cascades and Hauts-Bassins regions. Final report. 2016; 100.

[6] Saidi FZ. Determination of some hematological parameters in farmers exposed to pesticides in the Tlemeen region. Dissertation presented for obtaining the Master's degree in Biology, Algeria. 2012.

[7] Dallot C. Perturbation de la fonction thyroïdienne: mise en place d'une stratégie de criblage des produits chimiques. Sciences agricoles. Université Nice Sophia Antipolis, France. 2015.

[8] Leux C, Guénel P. Risk factors of thyroid tumors: Role of environmental and occupational exposures to chemical pollutants. Journal of Epidemiology and Public Health, 2010; 58(5): 359-367. 
[9] Khemiri R. La lambda-cyhalothrine comme pesticide privilégié en milieu agricole: Étude de la toxicocinétique des biomarqueurs pour le suivi de l'exposition chez des volontaires. Mémoire présenté à la Faculté des études supérieures en vue de l'obtention du grade de maitrise (M. SC.) en santé environnementale et santé au travail. Université de Montréal, Canada. 2017.

[10] Bayili B, Ouedraogo R, Ilboudo S, Pooda L, Bonkoungou M, al. Characterization of pesticides and practices of certain actors in the cotton zone around the biosphere of the Bala's hippopotamus pond in Burkina Faso. Journal of Experimental Biology and Agricultural Sciences. 2019; 7(6): 554 - 568.

[11] Campos E, Freire C. Exposure to non-persistent pesticides and thyroid function: A systematic review of epidemiological evidence. Int J Hyg Environ Health. 2016; 219(6): 481-97.

[12] Nedjma B. La physiologie et la physiopathologie de l'axe hypothalamo-hypophysaire. [Master]. Université des Frères Mentouri Constantine, Faculté des Sciences de la Nature et de la Vie, Algerie. 2018.

[13] Ntow WJ, Gijzen HJ, Kelderman P, Drechsel P. Farmer perceptions and pesticide use practices in vegetable production in Ghana. Pest Manag Sci. 2006; 62: 356-365.

[14] Gouda A-I, Toko II, Salami S-D, Richert M, Scippo M-L et al. Pratiques phytosanitaires et niveau d'exposition aux pesticides des producteurs de coton du nord du Bénin. Cah. Agric. 2018; 27: 65002.

[15] Pope C. The Influence of Age on Pesticide Toxicity. Hayes 'Handbook of Pesticide Toxicology. 2010; 819-835.

[16] Xiao X, Clark JM, Park Y. Potential contribution of insecticide exposure and development of obesity and type 2 diabetes. Food and Chemical Toxicology. 2017; 105: 456-474.

[17] Koech C. Pesticides as Obesogens: How pesticides are increasing sensitivity to metabolic disorders and how alternative pesticide practices need to be pursued. 2018.

[18] Ritz P, Dumas JF, Salle A, Simard G, Malthiery Y and Rohmer V. Thyroid hormones and obesity. Europe PubMed Central. 2002; 63(2Pt 1):135-139.

[19] Footprint PPDB. the Footprint Pesticide Properties Data Base. 2018.

[20] Kongtip P, Nankongnab N, Kallayanatham N, Pundee R, Choochouy N and al. Thyroid Hormones in Conventional and Organic Farmers in Thailand. International Journal of Environmental Research and Public Health. 2019; 16(15): 2704.

[21] Piccoli C, Cremonese C, Koifman RJ, Koifman S, Freire C. Pesticide exposure and thyroid function in an agricultural population in Brazil. Environmental Research. 2016; 151: 389-398.

[22] Bernieri T, Rodrigues D, Barbosa IR, Ardenghi PG, Basso da Silva L. Occupational exposure to pesticides and thyroid function in Brazilian soybean farmers. Chemosphere. 2018. 